\title{
Harmonization of Baja Upik Marriage with Indonesian Law System Based on Pancasila
}

\author{
YennyFebrianty \\ \{yennyfebrianty74@yahoo.com\} \\ Diponegoro University, Jl.Prof. H. Soedarto, S.H. Tembalang, Tembalang, Kota Semarang, Jawa \\ Tengah, 50275, Indonesia
}

\begin{abstract}
Harmonization of the Bajapuik local marriage rules in Padang Pariaman District area, which is inseparable from the implementation of rules in Indonesia Law system about Marriage. The terms and conditions about marriage in a universal way from Pluralism which governs the marriage method in Indonesia apply along with the released of Marriage Law No.1 Year 1974. Based on the above statement, the authors will examine and analyze the identification of problems, such as the existence of marriage "Bajapuik" today, the method's influence in social life in Padang Pariaman District community, and harmonization of local marriage Bajapuik rules in Padang Pariaman District with Indonesian law system based on Pancasila. The method used in this paper is socio-legal. The result of discussions in this paper shows that the development of law is seen as an attempt to change the law composition by planning purposely and directly encourage the future with trends tracking. Thus, law development means the renewal of law composition which includes three components, namely; law substance, law institutional, and law culture that includes attitude and behavior of officials and citizens concerning other components in organizing life process of obedient society. Pancasila also became the foundation of law culture of the Indonesian nation. The law must be based on Pancasila; law products may change based on the development of society and time. Pancasila should be the framework of thinking/ idea. Pancasila can guide national law culture in various fields. Meanwhile, the existence of Bajapuik marriage today is still maintained and run as a customary marriage ritual in the area of Padang Pariaman District, although it gives negative and positive impacts in the community of Padang Pariaman District.
\end{abstract}

Keywords: Baja Upik Marriage, State Law, Indigenous Law, Pancasila, Legal Pluralism

\section{Introduction}

Indonesia has a lot of Customary Law Customs that are different from one region to another. Customs diversity is a potential of the Indonesian nation and ancestral heritage as a nation that provides rules of behavior and human action in a custom observed by society.

In a study on customary law, the main thing is how to understand the way of life of the Indonesian nation, so it is obvious to say that the common law as an aspect of life and culture of Indonesia is a reflection of psychiatric and imagery thinking of Indonesia which can be seen through its common law. Customary law can be regarded as one of the legal cultures by its people for generations used to set the guidelines for living in a society of customary law. The life of indigenous and tribal peoples is linked by solidarity for equity, interests, and awareness. As the culture of law, customary law is the formulation of rules 
without going through the legislative establishment but is born from the popular opinions and sanctions reinforced by habit [1].

For the people of Indonesia, Pancasila values are even placed as a cultural paradigm of law. Pancasila has fundamental values that are universal and permanent. The values that are arranged hierarchically in the pyramid contain certain qualities that must be achieved by Indonesia which will translate into concrete reality in the life of society. [2] Pancasila also provided the basis for the legal culture of Indonesia. The law must be based on Pancasila, while the product may be changed by the law of the period and social development of society, in which Pancasila should be a framework of thinking. Pancasila can guide the national legal culture in various [3] fields, such as customary marriage law in the area of Padang Pariaman in West Sumatra.

When connected with the implementation of the marriage customs(bajapuik) in the district of Padang Pariaman, it is clear that the Marriage Law has no single article on setting the bajapuik marriage, but there is also no single article prohibits the customary bajapuik marriage.

Act No. 1 of 1974 provides direction ideals are lofty for fostering households between a man and a woman. According to customary law, marriage is a matter for relatives, family affairs, community affairs, personal affairs; and each other's relation is very different [4]. Customary law in the context of the development of new conceptual and reality is developed at this time. It cannot be isolated from its relationship with other laws, such as state law, religious law, customs, and even international law. Interrelationships, interactions, and interplays between the various systems of this law may compete, repel, or edify one another. Thus, the concept of the latest legal pluralism can be found in a variety of legal anthropological literature today. This is in line with Jentoft and Bavinck opinion that legal pluralism provides for compatibilities as well as possibilities for conflict between governing systems at each level. We return to this in the section 'Assessing the governing orders'[11].

The relationship between customary law and religious law itself has existed for so long, that the specific context has been difficult to separate; which the elements of customary law are and which the elements of religious law are. In Minangkabau society, for example, the arrival of Islam through a cultural approach, led to the emergence of the notion that Islam enhances customs, so such terminology was born: adatbasandisyara, syarabasandikitabullah, syaramanatoadatmamakai.[5]

\section{ApproachMethod}

Socio-legal Approach used in the research will get the data from both the law science and social science (interdisciplinary) aspects so that it can conduct an analysis of Bajapuik marriage harmonization within the Indonesian legal system that is based on Pancasila.

\section{Findings}

\subsection{The Existence of Bajapuik Marriage Today and Its Effect On The Social Life of Padang Pariaman Regency Society}

One of the general concepts of Bajapuik marriage is "menjemputmarapulai" (pick prospective bridegroom) to his parents' house by the bride to hold the marriage (ceremony) in the home of the female bride by bringing the requirements or conditions with applicable regulations according to the custom of marriage in that area. [6] 
Understanding money pickup in general needs an understanding from the family's side, the bride's, and the groom's. Money shuttle that happens when the family of a woman (girl or widow) would like to receive a man becomes a law. Sometimes a man and his family are not willing to marry, because the man does not have enough preparation and job security. Therefore, if a girl or her family wanted to take in a husband or son, then he should pick her up, either in the form of money, gold, vehicles, and so forth. [7].

The shuttle money practice could be seen as money lost which cause contradictory opinions between the pros and cons of this money. The pro arguments for agreeing to apply the money is missing, assuming that money shuttle (money lost) is a tradition in customs longstanding and should be preserved in culture. The pro considers that the issue of money shuttle is not liable parents, but also the responsibility of their uncles. Mawere and Mawere argued that customary marriage is building affinity and social capital among families, reducing family poverty, and preserving women dignity, among others [10].

If the preparation is not enough, it is customary to allow pawning inheritance. In connection with the traditional proverb is tired of saying the permissibility of the mortgaged inheritance for the things that are urgent needs, such as mayatterbujur di tengahrumah, rumahgadangketirisan, gadihgadangindakbalaki dan membangkitkantarehtarandam (dead body in the middle of the house, an adult girl with no husband awaken the submerged land).

From the author researched in 2002 on the use of money, the shuttle is a natural thing in customary marriage practices in the area of Padang Pariaman district. Money shuttle made to pay tribute to the groom and his family with the release of their sons from the longhouse (mansions) to build his household with his wife, the wife's family environment. There is an assumption that appears in this study that "diagiahkandakurangbalakupulolahkandakawak" (by request of the applicable precisely our request), means in terms of money pickups are granted by the family of the groom to present the terms of money shuttle to pick up men they were going to leave their life in the relatives' environment to start a new life in his family environment. If a family has a girl, the parents have prepared everything from the start to implement the terms of their daughters later marriage, including the shuttle that has been prepared for the money. On the other hand, there is a counter opinion regarding the application background of this lost money because they assume that the tradition is less aligned with the today situation. Due to the provision of this amount, the marriage is based on an assessment of the material, arising negative views from the outside area of Pariaman which states that Pariaman men "bought" the bride, causing outsiders to fear to take male Pariaman as a son-in-law or husband.

In connection with the purpose of money pick-up, money shuttle tradition was indeed difficult to separate from the people of Padang Pariaman, because they feel that something is missing without the money pick-up tradition. Therefore, the tradition still survives, and the people put up a farce that money pickups are not a problem. However, people on the shuttle are already agitated with the given money. It tends to be a burden for the public, due to the high currency becoming a prestige for the community. This, of course, would be a barrier between the poor and the rich, in which the poor have difficulties to provide the money, resulted in them not being able to hold a marriage. The expectations of the poor, who are economically weak, will never be reached. 


\subsection{Harmonization of Local Wisdom of BajapuikMarriageIn Padang Pariaman With The Legal System Based Pancasila Indonesia}

The birth of Marriage Act is by the principles of Pancasila and ideals of fostering the National Law need for a law on marriage that applies to all citizens.

Indonesia is a country rich in culture and tradition, which inevitably gave birth to a lot of customary laws of the various indigenous people. One of them is the customary marriage law which usually contains rules - rules, procedures, and consummation - inherited by the ancestors and are still be used and adhered to all members of the indigenous society. To understand and learn the customary marriage law itself, the arrangement pattern of society must be understood, whether it is matrilineal, patrilineal, parental, or territorial.[8]

Speaking about the legal system of marriage, it should be understood that the legal system meant here is the national legal system based on the ideology and constitutional state (Pancasila and the 1945 Constitution). In other words, the legal system is built on creativity and activity based on the engineering of the nation itself. On the other hand, it cannot be separated from the legal system patterned with pluralistic marriage. Indonesia has its characteristics drawn from the values that have been held before establishing a modern state. Those values form the values of tradition, culture, and religions, which are then crystallized into a value system called Pancasila. Within the meaning of constitutional state based on Pancasila, Indonesia as a nation has the nature of the community, kinship, and religions, and in this sense, the nation of Indonesia is mostly regarded as a divine nation of the Almighty. The formulation of Almighty God principle as contained in the 1945 Constitution has given a distinctive trait to the State of Indonesia, which is not a secular state that separates religion from the state, and not a religious-state built by a particular religion. The formulation of the supreme deity, which shows that Indonesia is a neither secular nor religious state, was made evident in Article 1 of Law Number 1 of 1974. It gives a sense that marriage is an emotional and physical bond between a man and a woman as husband and wife to form a loving and everlasting family (household) based on God's values. [9]

\section{Conclusion}

The existence of Bajapuikmarriagein Padang Pariaman area today remains alive as a tradition of local knowledge element that belongs to the local society, which is hereditary. In the culture of Padang Pariaman, Pariaman men who are married will stay with the bride's family. So this culture can be considered as giving a unique cultural assessment by looking at it from the angle of tolerance. Bajapuik culture necessarily implies mutual respect between men and women.

The alignment of the Bajapuik customary law marriage as one of the local wisdom Padang Pariaman with the rules of marriage as the national legal system should be based on the values of Pancasila.

\section{References}

[1] S. M. Pide,Customary Law In the past, Present and Future, Jakarta: Prenada Media, p 24-25, 2014

[2] Kaelan,Pancasila, Yogyakarta: Paradigma, p 70-71, 2010

[3] D. P.Rahayu,Culture Law Pancasila, Yogyakarta: Thafa Media, p 74, 2014. 
[4] T. Haarbzn,Principles and Organization of Customary Law, Jakarta: Pradnya Paramita p. 159, 1999.

[5] I. Sulistyowati, "Revitalisasi Hukum Adat yang Berperspektif Keadilan Jender." addressed at Regional Seminar,"Revitalisasi Hukum yang Berkeadilan Jender", Yogyakarta: FH Universitas Atmajaya, Sabtu. Vol. 17. 2004.

[6] B. Arifin, "Money Missing and Problem In Marriage In Pariaman,"Journal Res Fac Law, Univ Andalasp35. 1984

[7] N. Bakry,"Money Pickup and variation in the customary marriage in Pariaman and Its Effect on Social Life of Citizens,"Report Research, Padang,1984

[8] Supomo,Customary Law in Indonesia,Jakarta: Pradnya Paramita,1986

[9] T. Erwinsyahbana, "Marriage Law System Based On Pancasila State ofLaw," J Legal Stud3(1):17-22. 2011

[10] M. Mawere1 \&A. M. Mawere, "The changing philosophy of African marriage: The relevance of the Shona customary marriage practice of Kukumbira." Journal of African Studies and Development, Vol. 2(9), p. 224-233,2010.

[11] S. Jentoft, andM. Bavinck, "Interactivegovernanceforsustainablefisheries: dealingwith legal pluralism." Current Opinion in Environmental Sustainibility, Vol. 11, p. 71-77.2014. 